of Koninklijke Luchtvaart Mij.; Prof. E. Dennery : line New York-San Francisco of United Air Lines, Inc.). The services which aviation is able to render to geography and allied sciences were discussed by the following : M. A. Carlier, manager of the Société Générale de Photo-Topography (on aerial photography) ; Prof. P. George (on the role of aviation in the exploration of the polar regions); Father Poidebard (on the exploration of ancient civilizations by aeroplane) ; Prof. A. Demangeon (on the investigation of agricultural systems from the air); M. F. Blondel, chief mining engineer (how to employ the aeroplane for geological investigations and for prospecting); Prof. E. de Martonne (on the contribution of aviation to morphological studies); M. G. Huisman, directorgeneral of Fine Arts (on the aid of aviation in studying and conserving the architectonic treasures of France). There was also an interesting causerie by the well-known airman, M. P. Codos, on transcontinental and trans-oceanic flights. A number of other papers were of a more technical character.

It is to be regretted that the attendance at the Congress was not large; the date of the meeting had been chosen with regard to the sixteenth International Aeronautical Exhibition held at the Grand Palais des Champs-Elysées, but it is obviously not very convenient for a scientific congress. Though the meeting had been intended to be an international one, the speakers were, without a single exception, French, and nearly the same is true of the hearers, among whom there were only half a dozen foreigners. It is to be hoped that the next Congress of Aeronautical Geography, which will be held in 1940, again in Paris, may have larger and more international support.

Carl Hanns Pollog.

\title{
The Testing of Electrical Switchgear
}

$\mathrm{T}$ HE Department of Scientific and Industrial Research stated last year that at the request of a number of manufacturers of switchgear, it was considering the establishment of a short-circuit testing station at the National Physical Laboratory which would be capable of testing switchgear specified to be able to break a circuit having a current $I$ flowing in it with a possible maximum voltage $V$ across the gap of the circuit breaker, when the product of $V$ and $I$ is 250 million volt-amperes, certain limitations being made as to the value of $V$ and $I$. The cost of such a laboratory would be very high, as it would have to be built at an appreciable distance from other laboratories and it would have to generate its own power. Only a limited number of full-scale tests could be made per annum and so it would need a large Government grant.

The Department, therefore, issued a questionnaire to interested firms and bodies, inviting their views on various aspects of the proposal and on certain tentative proposals by means of which the National Physical Laboratory might be able to issue certificates that the gear has successfully passed certain specified tests. The replies disclosed a considerable measure of agreement. It was desirable to provide testing facilities which would be available for those manufacturers who did not possess testing stations, and that it should also be possible for such manufacturers to obtain certificates issued by an independent body in respect of such tests. At the same time, those companies which have already erected short-circuit testing stations for their own use indicated some doubt as to whether additional testing capacity in Great Britain was justified as there were already in existence greater testing facilities than are available in any other country in which switchgear is produced. They pointed out that they had spare capacity available. They offered to assist the Department in exploring the proposal further by supplying information from their own experience. As the result of most friendly discussions with the Department, it appeared possible to collaborate with the owners of existing short-circuit testing stations and so provide facilities in those stations for testing for any British manufacturer. Negotiations to this end began in 1937.
Agreement has been recently reached on a scheme which it is hoped will be adequate to meet requirements. This scheme permits the existing testing stations to continue to issue their own certificates, and in addition provides facilities for the issue of N.P.L. certificates when required in respect of circuit breakers coming within the agreed range which attain a standard of performance defined in the appropriate British Standards specification. The negotiations were made much easier by the fact that the owners of existing stations had already taken preliminary steps to co-ordinate their work and had provisionally decided to form an 'Association of Short-Circuit Testing Authorities' which would act as a testing or certifying body. This Association is now being incorporated. The main features of the new scheme are as follows. Owners of testing stations will provide facilities to any British manufacturer, without distinction, and will undertake that the fulltime use of one test bay will be made available collectively, by the existing testing plants, for tests for those manufacturers who do not themselves own testing stations. Tests will be normally carried out to the requirements of a definite British Standards specification. While the Association of Short-Circuit Testing Authorities will issue its own certificates of rating and records of performance, it will be possible to obtain N.P.I. certificates. Application for N.P.L. certificates under the arrangements should be addressed to the Director, National Physical Laboratory, who will decide at which station any individual test can be made. Strict confidence will be observed in connexion with the design of circuit-breakers submitted for test.

The stations at present included in the scheme are those of : The English Electric Co., Ltd., the General Electric Co., Ltd., the Switching Testing Co., Ltd., Trafford Park, which is jointly owned by the British Thomson-Houston Co., Ltd., Messrs. Ferguson Pailin, Ltd., and the Metropolitan-Vickers Electrical Co., Ltd.; The British Short-Circuit Testing Station, Ltd., Hebburn-on-Tyne, owned by Messrs. A. Reyrolle and Co., Ltd. As soon as the National Physical Laboratory is ready to receive orders for tests, leaflets giving full details of the arrangements for tests, including particulars of charges, will be available. 